\title{
Knowledge and attitude of menstruation hygiene, contraception and sexual transmitted disease among school girls of Lunawada, Mahisagar, Gujarat, India
}

\author{
Chintan Upadhyay ${ }^{1}$, Bipin Nayak ${ }^{1}$, Gaurav Desai ${ }^{2 *}$
}

\begin{abstract}
${ }^{1}$ Department of Obstetrics and Gynecology, ${ }^{2}$ Department of Community Medicine, GMERS Medical College and Civil
\end{abstract} Hospital, Gandhinagar, Gujarat, India

Received: 31 January 2018

Accepted: 06 March 2018

\author{
*Correspondence: \\ Dr. Gaurav Desai, \\ E-mail: dr_gauravdesai@yahoo.co.in
}

Copyright: () the author(s), publisher and licensee Medip Academy. This is an open-access article distributed under the terms of the Creative Commons Attribution Non-Commercial License, which permits unrestricted non-commercial use, distribution, and reproduction in any medium, provided the original work is properly cited.

\begin{abstract}
Background: Around $34^{\text {th }}$ of adolescent girls have experiencing menstrual dysfunction and it disturbs the routine daily workout4. UNICEF reported that total number of adolescent girls in India is 243 million which cover almost $20 \%$ of the Indian population. The objectives of the current study were to observe the knowledge and attitude regarding menstruation, contraception and sexually transmitted diseases among secondary and higher secondary school girls.

Methods: A cross-sectional study was conducted in the city of Vadodara during August 2016 to September 2016. The study included girls high school of standard $8^{\text {th }}$ to $12^{\text {th }}$ of Vadodara city. Around 310 adolescent students of standard $8^{\text {th }}, 9^{\text {th }}, 10^{\text {th }}, 11^{\text {th }}$, and $12^{\text {th }}$. From each standard, 62 girls were selected by simple random technique with the help of their attendance register.

Results: Around $71.4 \%$ participants believed that menstruation is natural process and $22.7 \%$ believed as abnormal process. Around $62.6 \%$ of participants believed for reason of menstruation is "Female becomes capable of child bearing". Almost 9.0\% participants did not know about organ of reproduction and $18.4 \%$ did not know about the physical changes during puberty. only $14.5 \%$ participants believed that coitus is the culprit of STD transmission. Teacher and mother were the main source of information for participants regarding STD. Almost 55.4\% participants were aware about condom as contraceptive method followed by oral pills and permanent sterilization.

Conclusions: Menstrual hygiene and prevention of STD diseases should be considered important issue at all the levels of health care system, where number of factor influence in the awareness and practice in rural area. Education regarding reproductive health should be included in the curriculum in all schools.
\end{abstract}

Keywords: Adolescent girl, Menstruation hygiene, Reproduction, Sexually transmitted disease

\section{INTRODUCTION}

Adolescence is duration of potent developmental and emotional period. According to World Health Organization (WHO), adolescent is belonged to age group of 10 to 19 years. ${ }^{1}$ Most landmark milestone of women's life is starting of menstruation is menarche.
Menarche is a sensitive indicator of nutritional status, geographical location, environmental conditions and prevalence of socioeconomic inequalities in the community. ${ }^{2-4}$ Around $3 / 4$ of adolescent girls have experiencing menstrual dysfunction and it disturbs the routine daily workout. UNICEF reported that total 
number of adolescent girls in India is 243 million which cover almost $20 \%$ of the Indian population. ${ }^{1}$

Another study found that adolescents compose $20 \%$ of the world's total population and out of that, $85 \%$ reside in developing countries. In India, prevalence of adolescent pregnancies was $10-15 \%$ of total pregnancies in India because of early marriage.

Most common reasons for visiting doctors by adolescent girls are delayed, irregular, painful, and heavy menstrual bleeding. In adolescent girls, most dominant reason of activity limitation and school absenteeism is Dysmenorrhea. But usually it is ignored due to being treated as physiological pain. ${ }^{5-7}$ Unplanned pregnancies are more reported among adolescents than adults which leads to sexually transmitted diseases including HIV/AIDS.

Most of adolescents still neither have approach to information and education on sexuality, reproduction, contraception and sexual and reproductive health and rights, nor do they have access to preventive and curative service. ${ }^{8}$

Teenage pregnancies considered as high-risk pregnancies result in unsafe abortions, low birth weight, and high maternal morbidity and mortality. Almost $40 \%$ HIV infection is found among teenagers. ${ }^{9}$

Study was conducted with objective to study the knowledge and attitude regarding menstruation, contraception and sexually transmitted diseases among secondary and higher secondary school girls.

\section{METHODS}

This was a cross-sectional study conducted at Secondary and higher secondary School, Mahisagar district, Gujarat during August-September 2016 after ethical permission of Intuitional Ethical Committee of GMERS Medical College, Gandhinagar, Gujarat.

A sample size of 310 was obtained using the hypothesis testing method and based on following assumptions: $95 \%$ confidence intervals, considering maximum prevalence of $50 \%$ (KAP on reproduction, contraception, and STDs among high school girls) and 5\% margin of error.

The calculated minimum sample had been inflated by $10 \%$ to account for anticipated subject nonresponse. For continuous variables mean and median had been calculated, and for categorical variables proportion and percentage had been obtained.

Study population included 310 adolescent students of standard $8^{\text {th }}, 9^{\text {th }}, 10^{\text {th }}, 11^{\text {th }}$, and $12^{\text {th }}$. From each standard, 62 girls were selected by simple random technique with the help of their attendance register. Data were collected with prior permission of school principal and informed consent was taken from participants before the questionnaire was administered.

\section{RESULTS}

Table 1 represents that mean age of participants was $15.1 \pm 1.4$ years. Highest numbers of participants $(33.0 \%)$ belonged to 16 years age. Almost $65.5 \%$ participants were residing in joint family. Around $44.2 \%$ and $35.5 \%$ participant's mother and father had got education up to primary level respectively.

Table 1: Socio-demographic information of participants $(\mathrm{N}=310)$.

\begin{tabular}{|l|l|}
\hline Variables & Number $(\%)$ \\
\hline Age (in years) & $4(1.3)$ \\
\hline 11 & $57(18.4)$ \\
\hline 13 & $56(18.1)$ \\
\hline 14 & $41(13.2)$ \\
\hline 15 & $102(32.9)$ \\
\hline 16 & $39(12.6)$ \\
\hline 17 & $11(3.5)$ \\
\hline 18 & $15.1 \pm 1.4$ \\
\hline Mean age (Mean \pm SD) & $107(34.5)$ \\
\hline Family type & $203(65.5)$ \\
\hline Nuclear & $66(21.3)$ \\
\hline Joint & $137(44.2)$ \\
\hline Mother education & $97(21.3)$ \\
\hline Illiterate & $10(3.2)$ \\
\hline Primary & \\
\hline Secondary/higher & $210(67.7)$ \\
\hline Secondary graduate/post graduate & $57(18.4)$ \\
\hline Mother occupation & $22(7.1)$ \\
\hline Housewife & $21(6.8)$ \\
\hline Unskilled worker & $4(1.3)$ \\
\hline Skill worker & $110(35.5)$ \\
\hline Services & $181(58.4)$ \\
\hline Father education & $15(4.8)$ \\
\hline Illiterate & $160(51.6)$ \\
\hline Primary & $80(25.8)$ \\
\hline Secondary/higher & $67(21.6)$ \\
\hline Secondary graduate/post graduate & $3(1.0)$ \\
\hline Father occupation & \\
\hline Unskilled worker & \\
\hline Service & \\
\hline Skilled worker & \\
\hline Unemployed & \\
\hline
\end{tabular}

Almost $67.7 \%$ mothers were working as housewife and $51.6 \%$ fathers were working as unskilled worker.

Table 2 denotes that $71.4 \%$ participants believed that menstruation is natural process and $22.7 \%$ believed as abnormal process. Around $62.6 \%$ of participants believed for reason of menstruation is "Female becomes capable of child bearing". 
Table 2: Distribution of participants according to their knowledge, attitude, and practice of menstruation $(\mathrm{N}=310)$.

\begin{tabular}{|l|l|}
\hline Variable & Number $(\%)$ \\
\hline What is menstruation & $221(71.4)$ \\
\hline Normal process & $68(22.7)$ \\
\hline Abnormal process & $5(1.6)$ \\
\hline Disease & $16(4.3)$ \\
\hline Do not know & \\
\hline Why menstruation occurs & $194(62.6)$ \\
\hline $\begin{array}{l}\text { Female becomes capable of child } \\
\text { bearing }\end{array}$ & $65(21.0)$ \\
\hline Cleans body of dirty blood & $33(10.6)$ \\
\hline Sign of attaining physical maturity & $18(5.8)$ \\
\hline Do not know & $148(47.7)$ \\
\hline Organ of reproduction & $103(33.2)$ \\
\hline Vagina & $31(10.0)$ \\
\hline Uterus & $28(9.0)$ \\
\hline Ovaries & $112(36.1)$ \\
\hline Do not know & $65(21.0)$ \\
\hline Physical changes during puberty & $54(17.4)$ \\
\hline Growth of pubic hair & $57(18.4)$ \\
\hline Breast budding & $22(7.1)$ \\
\hline Hair in the armpit & $6(1.9)$ \\
\hline Do not know & $216(69.7)$ \\
\hline Voice changes & $193(62.3)$ \\
\hline $\begin{array}{l}\text { Do you follow the ritual/restriction during } \\
\text { menstruation? }\end{array}$ & $59(19.0)$ \\
\hline No & $32(10.3)$ \\
\hline Yes & $11(3.5)$ \\
\hline Source of information & $9(2.9)$ \\
\hline Mother & \\
\hline Teacher & \\
\hline Elder sister & \\
\hline Friends & \\
\hline TV and radio & \\
\hline Book and magazine & \\
\hline
\end{tabular}

Almost $9.0 \%$ participants did not know about organ of reproduction and $18.4 \%$ did not know about the physical changes during puberty.

Around $69.7 \%$ participants had followed cultural ritual/restriction during menstruation. Mother is the most frequent source of information regarding menstruation among participants.

Table 3 indicates that $12.9 \%$ participants were not aware about the features of STD. Pain in lower abdomen was the commonest sign $(49.4 \%)$ felt by participants during menstruation followed by fever, redness of skin, itching sensation and burning micturition.

According to participants, vertical transmission (55.2\%) is the commonest mode of transmission of STD followed by syringe, blood transfusion and kissing.
Table 3: Distribution of participants according to their knowledge, attitude, and practice of Sexually transmitted diseases $(\mathrm{N}=310)$.

\begin{tabular}{|l|l|}
\hline Variables & Number $(\%)$ \\
\hline What are the sign/symptoms of STD? & \\
\hline Pain in the lower abdomen & $153(49.4)$ \\
\hline Fever & $98(31.6)$ \\
\hline Redness of skin & $59(19.0)$ \\
\hline Itching sensation & $55(17.7)$ \\
\hline Burning micturition & $51(16.5)$ \\
\hline Foul smelling discharge & $37(11.9)$ \\
\hline Genital ulcer & $25(8.1)$ \\
\hline Painful defecation & $10(3.2)$ \\
\hline Do not know & $40(12.9)$ \\
\hline Mode of transmission of STD & \\
\hline Vertical transmission & $171(55.2)$ \\
\hline Syringe & $126(40.6)$ \\
\hline Blood transfusion & $68(21.9)$ \\
\hline Kissing & $46(14.8)$ \\
\hline Coitus & $45(14.5)$ \\
\hline Hugging & $26(8.4)$ \\
\hline Shaking hands & $10(3.2)$ \\
\hline Do not know & $18(5.8)$ \\
\hline Source of Information & \\
\hline Teacher & $124(40.0)$ \\
\hline Mother & $106(34.2)$ \\
\hline Friends & $98(31.6)$ \\
\hline Books and magazines & $93(30.0)$ \\
\hline Health worker/doctor & $23(7.4)$ \\
\hline Relatives & $12(3.9)$ \\
\hline Preventive measures for STD & $51(16.5)$ \\
\hline Safe sex & $9(2.9)$ \\
\hline Safe blood transfusion & $5(1.6)$ \\
\hline Use of disposable syringe & $245(79.0)$ \\
\hline Do not know & \\
\hline
\end{tabular}

Almost 5.8\% participants did not know about mode of transmission of STD and only $14.5 \%$ participants believed that coitus is the culprit of STD transmission.

Teacher and mother were the main source of information for participants regarding STD. Table 4 signifies that $75.2 \%$ participants were aware about contraceptive methods. Almost $55.4 \%$ participants were aware about condom as contraceptive method followed by oral pills and permanent sterilization. Friend was the most frequent source $(26.8 \%)$ source of information about contraceptive method.

\section{DISCUSSION}

Poor knowledge in girls about contraception, STD (other than HIV/AIDS) and reproductive health is a matter of serious concern. ${ }^{1}$ Present study found mean age of participants was 15.1 years which higher than the similar study done by Das B et al, Deb T et al, Balasubramanian P et al, Goel MK et al, Khanna A et al, Haldar A et al, Grover $\mathrm{S}$ et al, Kumar D et al and Joshi BN et al where 
mean age was $10.7,12.0,13.5,13.1,13.2,13.0,17.2$, 16.8 and 10.8 years respectively.,9-15

Table 4: Distribution of participants according to their knowledge and attitude of contraception.

\begin{tabular}{|ll|}
\hline Variable & Number $(\%)$ \\
\hline Aware about sex education & \\
\hline No & $22(26.5)$ \\
\hline Yes & $28(73.5)$ \\
\hline Aware about any contraceptive method \\
\hline No & $77(24.8)$ \\
\hline Yes & $233(75.2)$ \\
\hline If yes, name the method (n=233) & $129(55.4)$ \\
\hline Condom & $127(54.5)$ \\
\hline Oral pills & $95(40.8)$ \\
\hline Female sterilization & $85(36.5)$ \\
\hline Male sterilization & $45(19.3)$ \\
\hline Copper - T & $9(3.9)$ \\
\hline Withdrawal & $8(3.4)$ \\
\hline Periodic abstinence & \\
\hline Source of information & $83(26.8)$ \\
\hline Friends & $75(24.2)$ \\
\hline Mother & $53(17.1)$ \\
\hline Health Worker/Doctor & $51(16.5)$ \\
\hline Teacher & $28(9.0)$ \\
\hline Media & $20(6.5)$ \\
\hline Books and magazines & \\
\hline
\end{tabular}

Study observed that less than $50.0 \%$ parents of participants had reached up to primary education level which is higher than the similar study done by Kumar D et al. ${ }^{4}$ This shows low literacy level at study setting area. Almost 2/3 participants of our study were belonged to joint family which quite higher than the similar study done by Kumar D et al which is because of difference in study setting area of both the studies.

Present study found that $2 / 3$ participants were of the view that menstruation is a normal cyclic process which is quit comparable with the similar study done by Khanna A et al and Dube $\mathrm{S}$ et al. ${ }^{4,16}$ Only $4.3 \%$ participants gave answer "Do not know" about menstruation process which is not comparable with similar study done by Dube $S$ et al, Khanna A et al and Kamalam JK et al.,16,17 Present study got satisfactory answer of the question 'reason of menstruation cycle' and 'physical changes during puberty' from higher number of participants. Regarding source of information, mother was the most frequent source. Similar finding was also observed by the similar study done by Das B et al, Kumar D et al, Nair P et al, Cakir M et al, Deo DS et al and Shanbhag D et al. In present study, around $69.7 \%$ participants had followed cultural ritual/restriction during menstruation which is higher than the similar study done by Das B et al. ${ }^{4,7,9,18-20}$

Almost $9.0 \%$ participants did not know about organ of reproduction which similar with the study done by Das B et al, Patel $\mathrm{P}$ et al, Drakshyani DK et al and Ali TZ et al. ${ }^{9,21-23}$ In present study, $12.9 \%$ participants were not aware about STD diseases which is very low in comparison to the similar study done by Das B et al, Tiwari VK et al and Grover S et al. ${ }^{9,11,24}$ This study found that pain in lower abdomen was the commonest sign (49.4\%) felt by participants during menstruation followed by fever, redness of skin, itching sensation and burning micturition. This finding is comparable with study done by Das B et al and Kumar D et al. ${ }^{9,14}$ Present study found low awareness regarding mode of transmission of STD which is not comparable with study done by Das B et al and Basir $\mathrm{G}$ et al. ${ }^{9,25}$

\section{CONCLUSION}

Menstrual hygiene and prevention of STD diseases should be considered important issue at all the levels of health care system, where number of factor influence in the awareness and practice in rural area. Education regarding reproductive health should be included in the curriculum in all schools. It can be given by didactic session, interpersonal communication, mass media, television and health lecture by specialist. Policy makers should be make policy regarding to increase awareness reproductive health especially in rural area.

\section{Funding: No funding sources \\ Conflict of interest: None declared}

Ethical approval: The study was approved by the Institutional Ethics Committee

\section{REFERENCES}

1. Grover S, Garg N, Rupali, Kaur B. Awareness about reproductive health, contraceptive methods, STDs including HIV/AIDS, and HPV vaccine, among adolescent girls in district Faridkot in Punjab. Int $\mathbf{J}$ Reprod Contracept Obstet Gynecol. 2017;6(5):20039.

2. Beek, Jonathan S. "Puberty and dysmenorrhea treatment". Novak's Gynecology. 14 ${ }^{\text {th }}$ ed. London: Williams and Wilkins publication Inc; 2006:1696.

3. Chumlea WC, Schubert CM, Roche AF, Kulin HE, Lee PA, Himes JH, et al. Age at menarche and racial comparisons in US girls. Pediat. 2003;111(1):110-3.

4. Kumar D, Goel NK, Puri S, Pathak R, Sarpal SS, Gupta S, et al. Menstrual Pattern among Unmarried Women from Northern India. J Clin Diagn Res. 2013;7(9):1926-9.

5. Ziv A, Boulet JR, Slap GB. Utilization of physician offies by adolescents in the United States. Pediat. 1999;104(1):35-42.

6. Malleshappa K, Krishna S, Nandini C. Knowledge and attitude about reproductive health among rural adolescent girls in Kuppam mandal: An intervention study. Biomed Res. 2011;22(3):305-10.

7. Cakir M, Mungan I, Karakas T, Girisken L, Okten A. Menstrual pattern and common menstrual disorders among university students in Turkey. Paediat Int. 2007;49(6):938-42. 
8. Kotecha PV, Patel S, Baxi RK, Mazumdar VS, Misra $\mathrm{S}$, Modi E, et al. Reproductive health awareness among rural school going adolescents of Vadodara district. Indian J Sex Transm Dis. 2009;30(2):94-9.

9. Das B, Desai GJ. KAP study of reproductive health and sexually transmitted diseases among high school girls of Vadodara city. Int J Med Sci Public Health. 2016;5(3):412-5.

10. Deb T, Mishra R. Need assessment of adolescents. Indian J Population Educ. 2005;6(1):3-17.

11. Balasubramanian P. Health needs of poor unmarried adolescent girls - A community-based study in rural Tamil Nadu. Indian J Popul Educ. 2005;6(1):18-33.

12. Goel MK, K Mittal, Knowledge regarding reproductive health among urban adolescent girls of Haryana. Indian J Community Med. 2010;35(4):52930.

13. Khanna A, Goyal SR, Bhawsar R. Menstrual practices and reproductive problems: A study of adolescent girls in Rajasthan. J Health Manag. 2005;7(1):91-107.

14. Haldar A, Ram R, Chatterjee T, Mishra R, Joardar GK. Study of need of awareness generation regarding component of reproductive and child health programme. Indian $\mathrm{J}$ Community Med. 2004;29(2):96-8.

15. Joshi BN, Chauhan SL, Dande UM, Tryambake VH, Gaitwad NS, Bhadoria V. Reproductive health problems and help seeking behaviour among adolescents in urban India. Indian $\mathrm{J}$ Pediatr. 2006;73(6):509-1.

16. Dube S, Sharma K. Knowledge, Attitude and Practice Regarding Reproductive Health among Urban and Rural Girls: A Comparative Study. Ethno Med. 2012;6(2):85-94.

17. Kamalam JK, Rajalakshmi B. Reproductive health awareness among college-going girls. Indian J Soc Work. 2005;66(4):414-30.

18. Nair P, Grover VL, Kannan AT. Awareness and practices of menstruation and pubertal changes amongst unmarried female adolescents in a rural area of East Delhi. Indian J Community Med. 2007;32(2):156-7.

19. Deo DS, Ghattargi CH. Perceptions and practices regarding menstruation: A comparative study in urban and rural adolescent girls. Indian J Community Med. 2005;30(1):33-4.

20. Shanbhag D, Shilpa R, D'Souza N, Josephine P, Singh J, Goud BR: Perceptions regarding menstruation and Practices during menstrual cycles among high school going adolescent girls in resource limited settings around Bangalore city, Karnataka, India. Int J Collab Res Intern Med. 2012,4(7):135362.

21. Patel P, Capoor I, Joshi U, Barge S, Uttekar VC. and society for operations research and training knowledge, awareness, belief and practice on sexuality and reproductive health of adolescent in slums of Ahmedabad. Small Research Grants Report. 2000;10:101-2.

22. Drakshayani Devi K, Venkata Ramaiah P. A study on menstrual hygiene among rural adolescent girls. Indian J Med Sci. 994;48(6):139-43.

23. Ali TS, Azam Ali P, Waheed H, Memon AA. Understanding of puberty and related health problems among female adolescents in Karachi, Pakistan. J Pak Med Assoc. 2006;56(2):68.

24. Tiwari VK, Kumar A. The need of sex education among youths: present perspectives and future prospects. Demogr India. 2002;31(1):129-59.

25. Basir G, Muzaffar A, Rehana K, Shabnam B. Knowledge, attitude and belief on HIV/AIDS among the female senior secondary students in Srinagar District of Kashmir. Health Popul Perspect Issues. 2003;26(3):101-9.

Cite this article as: Upadhyay C, Nayak B, Desai G. Knowledge and attitude of menstruation hygiene, contraception and sexual transmitted disease among school girls of Lunawada, Mahisagar, Gujarat, India. Int J Reprod Contracept Obstet Gynecol 2018;7:1543-7. 